\title{
Investigation of Magnetic Resonance Spectroscopy Findings in Patients with Absence Status Epilepticus
} Absans Status Epileptikusu Olan Hastalarda Manyetik Rezonans Spektroskopi
Bulgularının Araştırılması

\author{
Zeynep Aydın Özemir ${ }^{1}$, Betül Baykan¹, Ebru Nur Vanlı Yavuz ${ }^{1}$, Serra Sencer ${ }^{2}$ \\ 1 İstanbul University İstanbul Faculty of Medicine, Department of Neurology, Division of Clinical Neurophysiology, İstanbul, Turkey \\ 2ंstanbul University İstanbul Faculty of Medicine, Department of Radiology, İstanbul, Turkey
}

\section{Summary}

Objective: Absence status epilepticus (ASE) has been well recognized for many years, but its pathophysiology has not yet been illuminated and there are speculations about GABAergic mechanisms. We aimed to study the etiopathogenesis of ASE by using magnetic resonance-spectroscopy (MRS), which gives in vivo information about neuronal loss and/or dysfunction by correlating the results with age- and sex-matched normal healthy controls (HC).

Materials and Methods: Four patients with genetic generalized epilepsy (GGE), which was diagnosed in accordance with the International League Against Epilepsy criteria, with recurrent ASE were investigated. The control groups consisted of ten age- and sex-matched patients with HC and ten patients with GGE. MRS measurements of $\mathrm{N}$-acetylaspartate (NAA), choline-containing compounds (Cho), and creatine (Cr) were performed in the frontal lobes and thalamus bilaterally with a voxel size of 20x20x20 mm, the values of the patients were compared with those of the controls using appropriate statistical tests.

Results: In patients with ASE, NAA/Cr levels were decreased when compared with those with HC and GGE in the frontal lobes and thalamus. Moreover, frontal lobe Cho values and $\mathrm{Cho} / \mathrm{Cr}$ ratios were elevated in all patients with GGE, and more pronounced in patients with ASE comparison with those with HC. There was a positive correlation of ASE with the frontal $\mathrm{Cho} / \mathrm{Cr}$ ratio and a negative correlation with $\mathrm{NAA} / \mathrm{Cr}$ ratios in patients with GGE ( $\mathrm{p}=0.002, \mathrm{z}=-0.745$ ). The presence of absence seizures related negatively to the thalamic NAA/Cr ratio and NAA levels. Prognosis showed a negative correlation with thalamic NAA levels $(\mathrm{p}=0.026, \mathrm{z}=-0.591)$ and the NAA/Cr ratio $(\mathrm{p}=0.013, \mathrm{z}=-0.645)$.

Conclusion: Although our sample size was small due to the rarity of the condition, this first MRS study in patients with ASE showed that neuronal dysfunction in frontal lobes and thalamus was more pronounced when compared with those with GGE and related to poor prognosis. Our study suggested that the dysfunction in thalamocortical circuits might underlie ASE attacks.

Keywords: Absance, status epilepticus, magnetic resonance spectroscopy

\section{$\ddot{O} \mathbf{z}$}

Amaç: Absans status epileptikus (ASE) çok uzun yıllardır tanınan bir tablo olmakla birlikte patofizyolojisi henüz bilinmemektedir ve GABAerjik mekanizmalar üzerinde durulmaktadır. Bu çalışmada nöronal kayıp ve/veya disfonksiyon hakkında in vivo olarak bilgi veren manyetik rezonans spektroskopi (MRS) yapılarak ve sağlıklı kontrollerle (SK) kıyaslanarak ASE'nin etiyopatogenezini aydınlatmaya yönelik bilgiler edinmek amaçlanmıştır.

Gereç ve Yöntem: Tekrarlayan ASE atakları olan ve 'Uluslararası Epilepsi ile Savaş Ligi' tarafından yapılmış sınıflamaya göre genetik jeneralize epilepsi (GJE) tanısı almış dört hasta incelenmiştir. Talamus ve frontal loblara ayrı ayrı 20x20x20 mm boyutlarında vokseller yerleştirilmiş ve elde edilen $\mathrm{N}$-asetil aspartat (NAA), kolin (Ko) ve kreatin $(\mathrm{Kr})$ değerleri yaş ve cins olarak eşlenmiş on SK ve on diğer GJE tanısı almış olan kontrol gruplarıyla uygun istatistiksel yöntemlerle kıyaslanmıştır.

Address for Correspondence/Yazışma Adresi: Zeynep Aydın Özemir MD, İstanbul University İstanbul Faculty of Medicine, Department of Neurology, Division of Clinical Neurophysiology, İstanbul, Turkey

Phone: +90 5058032126 E-mail: drzeynepaydin@yahoo.com

Received/Geliş Tarihi: 10.11.2015 Accepted/Kabul Tarihi: 11.02.2016 
Bulgular: ASE hastalarında frontal lob ve talamus NAA/Kr oranları SK'lara ve diğer GJE'lilere göre düşük, ayrıca frontal lob Ko değerleri, Ko/Kr oranları ASE grubunda daha belirgin olmak üzere tüm GJE hastalarda normallere kıyasla yüksek saptanmıştır. GJE'li hastalarda ASE varlığı ile; frontal Ko/Kr oranı arasında pozitif, frontal $\mathrm{NAA} / \mathrm{Kr}$ oranı arasında negatif, talamus NAA/Kr oranı arasında negatif ( $\mathrm{p}=0,002, \mathrm{z}=-0,745)$ ilişki kaydedilmiştir. Absans nöbet varlığ 1 ile; talamus NAA/Kr oranı ve NAA düzeyi ile arasında negatif ilişki bulunmuştur. Prognoz ile talamus NAA düzeyi arasında ( $\mathrm{p}=0,026, \mathrm{z}=-0,591)$ ve NAA/Kr oranı arasında $(\mathrm{p}=0,013, \mathrm{z}=-0,645)$ negatif korelasyon saptanmıştır.

Sonuç: Çok nadir rastlanması nedeniyle olgu sayımız az olmakla birlikte, ASE'li olgularda yapılan bu ilk çalışmada frontal loblarda ve talamusta MRS ile saptanan nöronal fonksiyon bozukluğunun ASE atakları olmayan GJE’lilere göre daha fazla olduğu ve bozukluğun prognozu olumsuz etkilediği gösterilmiştir. Çalışmamız talamo-kortikal devrelerdeki bu bozukluğun ASE ataklarının altında yattı̆̆ını düşündürmüştür.

Anahtar Kelimeler: Absans, status epileptikus, manyetik rezonans spektroskopi

\section{Introduction}

Absence status epilepticus (ASE), which is classified under the "generalized" sub-group of "non-convulsive status epilepticus without coma" according to the latest classification (1), is an epileptic condition affects consciousness in varying degrees and may be accompanied by automatisms or mild myoclonic, tonic, atonic or autonomic phenomena (2). Alterations in behavior and consciousness of more than 5 minutes and presence of generalized epileptiform electroencephalographic (EEG) abnormalities during this period are required for the diagnosis of ASE. Although more frequent (about 20\%) in patients with juvenile absence epilepsy (JAE), ASE may develop in genetic generalized epilepsy (GGE) at a rate of $5-10 \%(3,4)$. The mechanisms of absence seizures and ASE are not yet clear, but it is thought that the thalamocortical network is affected and that disorders in gamma-aminobutyric acid-mediated inhibitory mechanisms, which are normally effective in terminating seizures, and changes in N-methyl-D-aspartate receptors play a role in the pathogenesis. Also, it is not known whether ASE causes damage to the brain $(5,6,7,8,9)$. Magnetic resonance spectroscopy (MRS) is a non-invasive, in vivo examination method for measuring rates of specific chemical metabolites in tissues (10). MRS makes measurements on three major metabolites, namely $\mathrm{N}$-acetyl aspartate (NAA), creatine+phosphocreatine $(\mathrm{Cr})$, and choline-containing compounds (Co) (Figure 1). When a decrease in NAA signal is observed, which is known to be present in neurons and their extensions $(10,11)$, it is thought to be due to neuronal or axonal loss or metabolic disorder caused by mitochondrial dysfunction and these changes are generally considered to be irreversible $(11,12,13)$. Although MRS studies have been conducted more on patients with focal epilepsy, especially patients with temporal lobe epilepsy, recent studies on patients with GGE are also available. Despite these studies had varying results, decreased NAA and NAA/Cr levels were detected in the frontal lobes $(14,15)$ and the thalamus $(16,17)$ of patients with GGE compared with controls. There are no previous MRS studies on patients with ASE. The aim of this study was to investigate the neurochemical changes in the frontal lobe and thalamus of patients with ASE using MRS and thus to illuminate the underlying etiopathogenesis, and to detect whether recurrent ASE attacks cause brain damage.

\section{Materials and Methods}

\section{Selection and Grouping of Patients}

Among the patients being followed up by the Neurology Department of İstanbul Faculty of Medicine, İstanbul University, patients who were diagnosed as having GGE in accordance with the International League Against Epilepsy (ILAE) classification (18) with consistent seizure semiology and history, EEG findings and other records were investigated. Among these, four patients with recurrent ASE attacks formed the study group. Ten patients with GGE and 10 previously healthy individuals with similar age and sex distributions were included in the study as the GGE group and healthy control (HC) group, respectively. Demographic and clinical data, interviews with patients and their relatives, and follow-up and treatment data were examined in detail from patients' files. This study protocol was approved by İstanbul Medical Faculty Ethics Committee and patients were included in the study after obtaining written informed consents. The patient
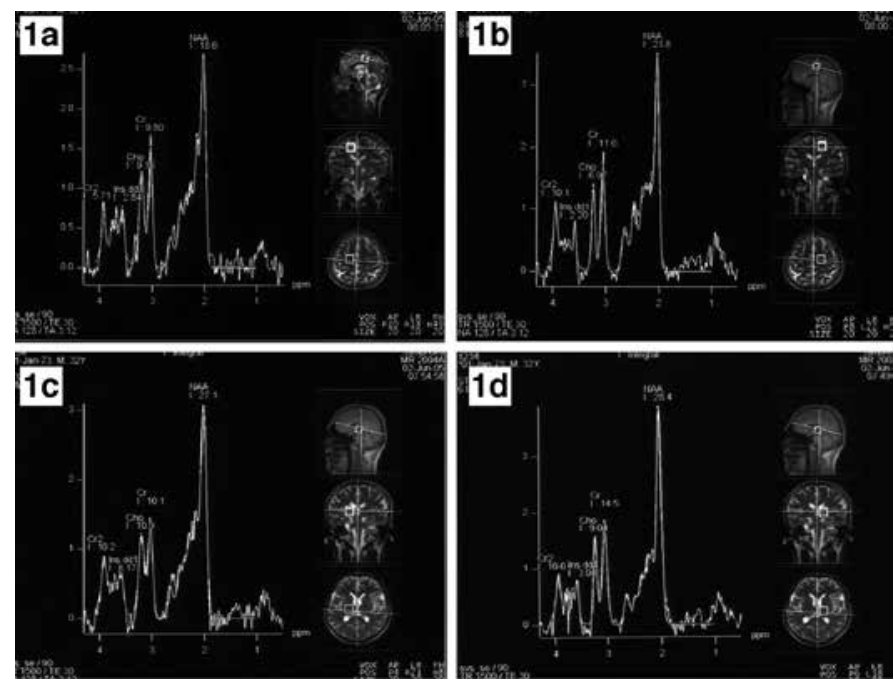

Figure 1. Voxels and obtained curves in patients for magnetic resonance spectroscopy examination. Voxels placed to include cortico-subcortical areas and obtained magnetic resonance spectroscopy values in a male patient aged 32 years with juvenile absence epilepsy; a, b) Frontal lobe voxels; c, d) Thalamic voxels 
group was evaluated in terms of syndrome diagnosis based on the ILAE syndrome classification (18), age of onset, duration of epilepsy, types of seizures, presence of absence, myoclonus, generalized tonic-clonic seizures and age of onset, frequency of these seizure types before and after treatment, date of most recent seizure, seizure trigger factors, past and current treatments, presence of discontinuation of medications duration treatment and if so, presence of recurrence, length of time without medication, duration of treatment, response to treatment, presence of psychiatric and other systemic diseases, and presence of remission and family history of epilepsy sub-groups were formed.

Magnetic Resonance Imaging and Proton Magnetic Resonance Spectroscopy

MRI and 1-H MRS examinations were performed in all patients and healthy volunteers in the Neuroradiology Department of İstanbul Faculty of Medicine, İstanbul University. MRI examinations were performed using an MRI unit (Magnetom Symphony, Siemens, Erlangen, Germany) with a 1.5 Tesla (T) superconducting magnet. Following acquisition of scout images in axial, sagittal, and coronal planes using standard head coil, axial, coronal and sagittal T2-weighted (A) turbo spin echo $(\mathrm{TR} / \mathrm{TE}=5750 / 100 \mathrm{~ms}, \mathrm{NEX}=1$, slice thickness of 5 $\mathrm{mm}$, matrix $=512 \times 512, \mathrm{FOV}=220 \mathrm{~mm}$ ), and coronal inversion recovery T1 (IR T1) $(\mathrm{TR} / \mathrm{TE}=1960 / 4 \mathrm{~ms}, \mathrm{IT}=1100 \mathrm{~ms}, \mathrm{NEX}=1$, slice thickness of $1.25 \mathrm{~mm}$, matrix $=512 \times 512, \mathrm{FOV}=220 \mathrm{~mm}$ ) sequences were obtained. Following these sequences, 20x20x20 $\mathrm{mm}$ single voxels were placed separately to thalamic and frontal regions of both hemispheres using the stimulated-echo acquisition mode ( $\mathrm{TR} / \mathrm{TE}=1500 / 30 \mathrm{~ms}$ ) and chemical shift selective excitation for water suppression (Figure 1). NAA, Co, and Cr peaks obtained from these voxels were compared proportionally. These single voxel values were processed using Syngo MRS software. Curves obtained after "curve fitting" and "curve correction" processes that were performed automatically by the software were checked by a neuroradiology practitioner. Erroneous curves were corrected manually via a software interface and integral values were calculated automatically using the device's software. NAA, Co, and $\mathrm{Cr}$ peaks were included at approximately 2.02, 3.22 and 3.02 part per million (ppm), respectively.

\section{Statistical Evaluation}

SPSS 20.0 software was used for statistical analysis and $\mathrm{p}<0.05$ was considered as statistically significant. The distribution of numeric variables obtained by MRS was evaluated using histograms and the distribution was found as not normal. Therefore, the Kruskal-Wallis $\mathrm{H}$ test was run to determine whether there were differences between the three groups and the Mann-Whitney $\mathrm{U}$ test was used to determine differences between two groups. The strength and direction of the association between numeric variables and nominal and ordinal variables were performed using Spearman's rho test.

\section{Results}

\section{Clinical Findings}

The mean ages of the groups were as follows: $34.6 \pm 12.5$ years (range, 22-52 years) in the ASE group ( $3 \mathrm{~F}, 1 \mathrm{M}$ ), 23.8 \pm 5.91 years (range, 16-33 years) in the GGE group ( $7 \mathrm{~F}, 3 \mathrm{M}$ ), and $30 \pm 11.65$ years (range, 18-56 years) in the $\mathrm{HC}$ group ( $7 \mathrm{~F}, 3 \mathrm{M}$ ). Cranial images of all patients in the patient and control groups were within normal limits. Prognosis was significantly worse in the ASE group compared with the GGE group. The clinical characteristics of patients with ASE and GGE are shown in Table 1.

\section{Magnetic Resonance Spectroscopy Findings}

The comparison of MRS metabolite levels of groups revealed significant differences between frontal Co levels, $\mathrm{Co} / \mathrm{Cr}$ ratios, $\mathrm{NAA} / \mathrm{Cr}$ ratios, and thalamic NAA levels and $\mathrm{NAA} / \mathrm{Cr}$ ratios (Tables 2, 3, Figure 2a). Frontal $\mathrm{Co}$ and $\mathrm{Co} / \mathrm{Cr}$ levels were highest in the ASE group, followed by GGE and HC groups (Figure 2b). In contrast, NAA levels were lowest in the ASE group. NAA levels were a little higher in the GGE group than in the ASE group, but lower compared with the HC group. Thalamic NAA level and $\mathrm{NAA} / \mathrm{Cr}$ ratio were statistically significantly lower in the ASE group compared with the GGE and HC groups in the between-group comparisons. These values were also found lower in the GGE group than in the $\mathrm{HC}$, but the difference was not statistically significant. In addition, the frontal NAA levels and $\mathrm{NAA} / \mathrm{Cr}$ ratio were lower in the ASE group compared with the $\mathrm{HC}$ group. Frontal $\mathrm{Co}$ levels and $\mathrm{Co} / \mathrm{Cr}$ ratios were significantly higher in the ASE and GGE groups compared with the HC group. Although frontal Co levels and the $\mathrm{Co} / \mathrm{Cr}$ ratio were higher in the ASE group compared with the GGE group, there was no statistically significant difference. The following correlations were found for the presence of ASE in patients with GGE: positive correlation $(\mathrm{p}=0.04, \mathrm{z}=-0.549)$ with frontal $\mathrm{Co} / \mathrm{Cr}$ ratio, negative correlation $(\mathrm{p}=0.016, \mathrm{z}=-0.628)$ with frontal $\mathrm{NAA} / \mathrm{Cr}$ ratio and negative correlation $(\mathrm{p}=0.002, \mathrm{z}=-0.745)$ with the thalamic NAA/ $\mathrm{Cr}$ ratio. There were negative correlations between the presence of absence seizures and the thalamic NAA/Cr ratio $(\mathrm{p}=0.009, \mathrm{z}=-$ $0.230)$ and thalamic NAA levels $(\mathrm{p}=0.004, \mathrm{z}=-0.572)$. There were
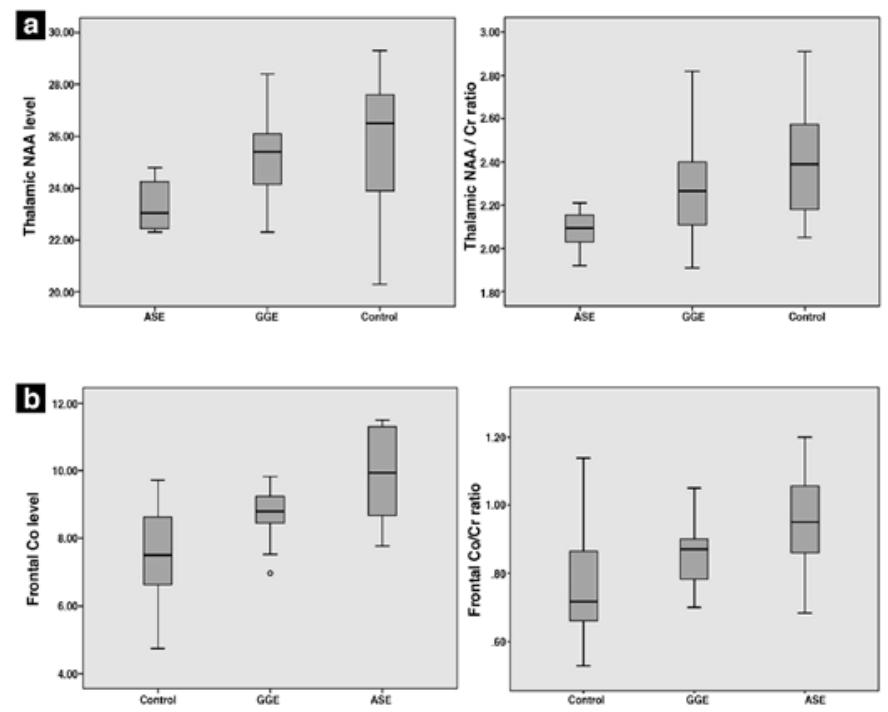

Figure 2. Different magnetic resonance spectroscopy metabolite levels between groups; a) Thalamic $\mathrm{N}$-acetyl aspartate and $\mathrm{N}$-acetyl aspartate/ creatine levels were observed to be the lowest in the absence status epilepticus group, b) Frontal lobe choline and choline/creatine levels were increased in the absence status epilepticus group 


\begin{tabular}{|c|c|c|c|c|}
\hline \multicolumn{2}{|l|}{ Clinical characteristics } & $\operatorname{ASE}(n=4)$ & GJE $(n=10)$ & Statistical results \\
\hline \multicolumn{2}{|c|}{ The age of onset of epilepsy (years)* } & $19.38 \pm 13.889(2-35)$ & $13.35 \pm 5.764(5-22)$ & Not significant \\
\hline \multicolumn{2}{|c|}{ The age of onset of ABS (years)* } & $20.88 \pm 18.984(2-47)$ & $14.58 \pm 8.357(5-28)$ & \\
\hline \multicolumn{2}{|c|}{ The age of onset of MYC (years)* } & $23.33 \pm 10.116(17-35)$ & $14.67 \pm 5.465(6-22)$ & Not significant \\
\hline \multicolumn{2}{|c|}{ The age of onset of GTCS (years)* } & $21.75 \pm 8.846(17-35)$ & $15.67 \pm 6.022(6-22)$ & Not significant \\
\hline \multicolumn{2}{|c|}{ Duration of epilepsy (years)* } & $15.1 \pm 5.571(7.7-20.9)$ & $10.5 \pm 7.131(1.8-23.8)$ & Not significant \\
\hline \multicolumn{2}{|c|}{ Family history of epilepsy $(\mathrm{n} / \%)^{\dagger}$} & $1(25)$ & $4(40)$ & Not significant \\
\hline \multirow{6}{*}{$\begin{array}{l}\text { All seizure types } \\
(\mathrm{n} / \%) \ddagger\end{array}$} & MYC & -- & $1(10)$ & \\
\hline & Absence & -- & $2(20)$ & \\
\hline & Absence+GTC & -- & $1(10)$ & \\
\hline & MYC+Absence & -- & $1(10)$ & Not significant \\
\hline & MYC+GTC & -- & $1(10)$ & \\
\hline & MYC+GTC+Absence & $4(100)$ & $4(40)$ & \\
\hline \multirow{3}{*}{$\begin{array}{l}\text { Initial MYC frequency } \\
(\mathrm{n} / \%)^{\ddagger}\end{array}$} & $\geq 30$ per month & $1(10)$ & $3(30)$ & \\
\hline & $<30, \geq 4$ per month & $1(10)$ & $4(10)$ & Not significant \\
\hline & $<4$ per month & $2(20)$ & -- & \\
\hline \multirow{4}{*}{$\begin{array}{l}\text { Recent MYC frequency } \\
(\mathrm{n} / \%)^{\ddagger}\end{array}$} & $\geq 30$ per month & - & -- & \\
\hline & $<30, \geq 4$ per month & $2(50)$ & $2(20)$ & \\
\hline & $<4$ per month & -- & $1(10)$ & Not signiticant \\
\hline & None for at least 2 years & $2(50)$ & $5(50)$ & \\
\hline \multirow{3}{*}{$\begin{array}{l}\text { Initial GTCS frequency } \\
(\mathrm{n} / \%)^{\ddagger}\end{array}$} & $\geq 12$ annually & -- & -- & \\
\hline & 2-11 annually & $1(10)$ & $3(30)$ & \\
\hline & $<2$ annually & $3(30)$ & $3(30)$ & Not significant \\
\hline \multirow{3}{*}{$\begin{array}{l}\text { Recent GTC frequency } \\
(\mathrm{n} / \%)^{\ddagger}\end{array}$} & 2-11 annually & -- & -- & \\
\hline & $<2$ annually & -- & -- & Not significant \\
\hline & None for 2 years & $4(100)$ & $6(60)$ & \\
\hline \multirow{2}{*}{$\begin{array}{l}\text { Initial ABS frequency } \\
(\mathrm{n} / \%)^{\dagger}\end{array}$} & $\geq 1$ per week & $2(50)$ & $4(40)$ & \\
\hline & $<3$ per month & $2(50)$ & $3(30)$ & Not significant \\
\hline \multirow{3}{*}{$\begin{array}{l}\text { Recent ABS frequency } \\
(\mathrm{n} / \%)^{\ddagger}\end{array}$} & None for 4 years & $1(25)$ & $6(60)$ & \\
\hline & Rare ( 1 per month) & $1(25)$ & $1(10)$ & Not significant \\
\hline & $\geq 1$ per week & $2(50)$ & -- & \\
\hline \multirow{4}{*}{$\begin{array}{l}\text { Recent treatment } \\
(\mathrm{n} / \%)^{\ddagger}\end{array}$} & VPA & $3(75)$ & $4(40)$ & \\
\hline & LEV & -- & $3(30)$ & Not significant \\
\hline & $\mathrm{VPA}+\mathrm{LEV}$ & (25) & $2(20)$ & \\
\hline & No medication & & $1(10)$ & \\
\hline \multirow[t]{3}{*}{ Prognosis $\dagger$} & Good & -- & $8(80)$ & \\
\hline & Moderate & $4(100)$ & $2(20)$ & \\
\hline & Refractory & -- & -- & $\mathrm{p}=0.015$ \\
\hline \multirow[t]{4}{*}{ Syndrome $(\mathrm{n} / \%)^{\ddagger}$} & CAE & -- & $1(10)$ & \\
\hline & JAE & -- & $2(20)$ & \\
\hline & JME & $1(25)$ & $7(70)$ & $\mathrm{p}=0.021$ \\
\hline & $\begin{array}{l}\text { Atypical GGE with } \\
\text { recurrent ASE }\end{array}$ & $3(75)$ & -- & $p-0.021$ \\
\hline
\end{tabular}


negative correlations between prognosis and thalamic NAA levels $(\mathrm{p}=0.026, \mathrm{z}=-0.591)$ and the NAA/Cr ratio $(\mathrm{p}=0.013, \mathrm{z}=-0.645)$.

\section{Discussion}

In several studies in few patients with GGE, thalamic NAA/ $\mathrm{Cr}$ ratio has been found to be decreased in the patient groups compared with controls, thus demonstrating a disorder in thalamic neuronal metabolism, which supports the idea that the origin of the seizures is an abnormality in the thalamocortical network $(19,20,21)$. In addition, in MRS studies, frontal lobe
NAA levels in patients with GGE have been found decreased compared with controls and prefrontal dysfunction has been shown particularly in GGE; the etiology of these neuronaloriginated changes is not yet clear, but might be associated with regional possible cortical dysplasia at a microscopic level $(14,15)$. In our study, the detection of decreases in NAA levels and NAA/ $\mathrm{Cr}$ ratios in all patients with GGE that were significantly lower in patients with recurrent ASE compared with patients without ASE episodes suggests that recurrent ASE episodes are caused by more prominent thalamic dysfunction and neuronal loss when compared with HC using thalamic voxels. On the other hand, it

\begin{tabular}{|c|c|c|c|c|c|}
\hline Group & & Minimum & Maximum & Mean & $\begin{array}{l}\text { Standard } \\
\text { deviation }\end{array}$ \\
\hline \multirow{10}{*}{ Control } & Thalamic Co & 6.11 & 11.60 & 8.6635 & 1.32422 \\
\hline & Thalamic Cr & 9.69 & 12.90 & 11.1245 & 0.90804 \\
\hline & Thalamic $\mathrm{Co} / \mathrm{Cr}$ & 0.44 & 1.12 & 0.7772 & 0.15943 \\
\hline & Thalamic NAA & 20.30 & 29.30 & 25.8500 & 2.35674 \\
\hline & Thalamic NAA/Cr & 2.05 & 2.91 & 2.4013 & 0.25434 \\
\hline & Frontal Co & 4.75 & 9.72 & 7.5960 & 1.33113 \\
\hline & Frontal Cr & 8.18 & 11.90 & 10.2730 & 0.85248 \\
\hline & Frontal $\mathrm{Co} / \mathrm{Cr}$ & 0.53 & 1.14 & 0.7480 & 0.14699 \\
\hline & Frontal NAA & 19.70 & 30.00 & 23.6750 & 2.65070 \\
\hline & Frontal NAA/Cr & 1.95 & 3.11 & 2.3265 & 0.27178 \\
\hline \multirow{10}{*}{ ASE } & Thalamic Co & 6.96 & 11.60 & 9.2237 & 1.63536 \\
\hline & Thalamic Cr & 10.20 & 12.00 & 11.1750 & 0.68817 \\
\hline & Thalamic Co/Cr & 0.59 & 0.97 & 0.8055 & 0.12707 \\
\hline & Thalamic NAA & 22.30 & 24.80 & 23.3250 & 1.00534 \\
\hline & Thalamic NAA/Cr & 1.92 & 2.21 & 2.0862 & 0.09319 \\
\hline & Frontal Co & 7.77 & 11.50 & 9.8863 & 1.45953 \\
\hline & Frontal Cr & 7.78 & 14.60 & 11.0225 & 2.26631 \\
\hline & Frontal $\mathrm{Co} / \mathrm{Cr}$ & 0.68 & 1.20 & 0.9521 & 0.16855 \\
\hline & Frontal NAA & 17.90 & 26.60 & 21.4250 & 3.03962 \\
\hline & Frontal NAA/Cr & 1.49 & 2.43 & 1.9637 & 0.32820 \\
\hline \multirow{10}{*}{ GGE } & Thalamic Co & 7.16 & 11.10 & 9.1810 & 0.92088 \\
\hline & Thalamic Cr & 8.41 & 14.50 & 11.6905 & 1.54293 \\
\hline & Thalamic Co/Cr & 0.62 & 1.03 & 0.8034 & 0.11183 \\
\hline & Thalamic NAA & 22.30 & 28.40 & 25.2550 & 1.47772 \\
\hline & Thalamic NAA/Cr & 1.91 & 2.82 & 2.2890 & 0.24721 \\
\hline & Frontal Co & 6.97 & 9.83 & 8.7905 & 0.71335 \\
\hline & Frontal $\mathrm{Cr}$ & 7.75 & 13.40 & 10.2825 & 1.32039 \\
\hline & Frontal $\mathrm{Co} / \mathrm{Cr}$ & 0.70 & 1.05 & 0.8568 & 0.09101 \\
\hline & Frontal NAA & 18.60 & 27.20 & 22.2900 & 2.86942 \\
\hline & Frontal NAA/Cr & 1.62 & 2.74 & 2.1885 & 0.29596 \\
\hline
\end{tabular}




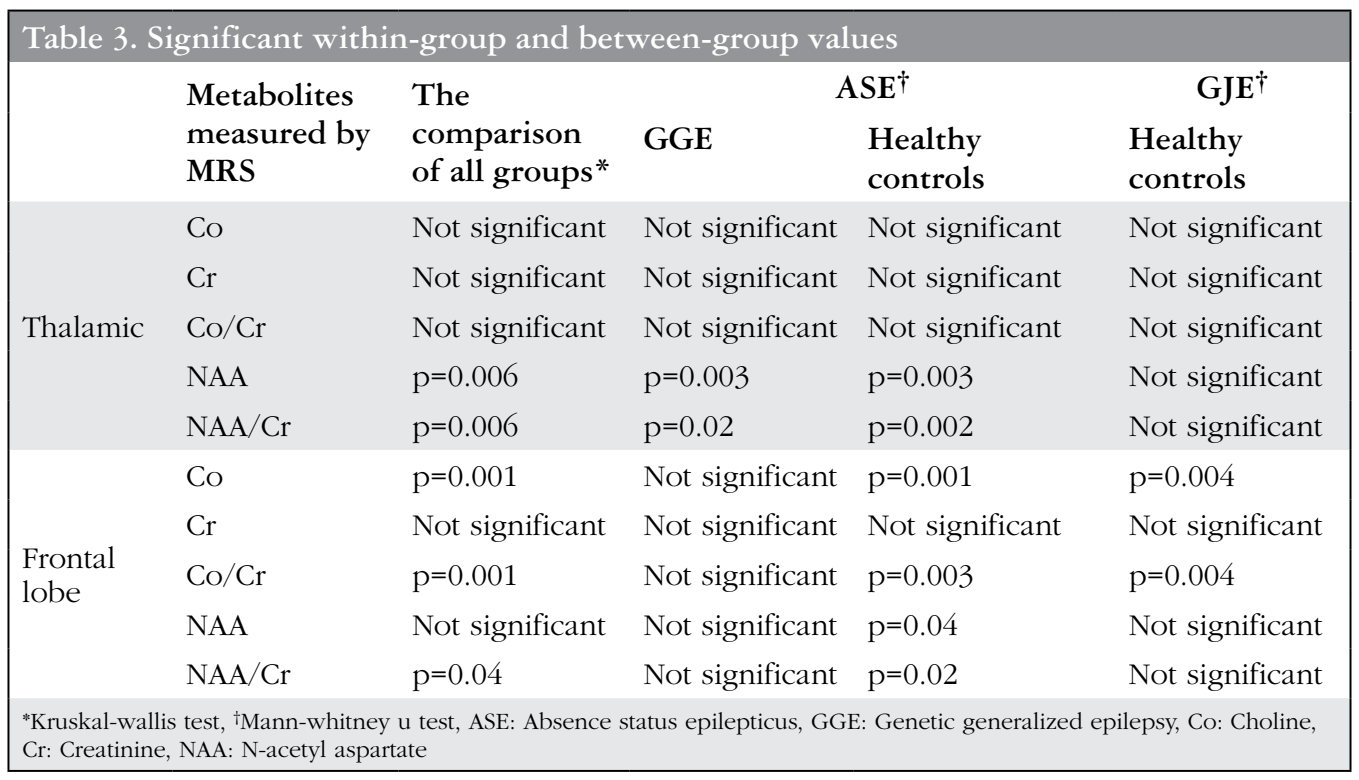

is thought that recurrent ASE episodes might have caused this damage. At the same time, supporting the literature, similar findings, more prominent in patients with ASE episodes were detected in frontal cortex of all patients with GGE. However, the presence of both frontal cortical and thalamic prominent involvement in patients with ASE refers to a probable difference in thalamocortical cycle in the etiopathogenesis of recurrent ASE episodes or to the probability of occurrence of this dysfunction also as a result of episodes. In our study, the determination of a worse prognosis in these patients supports this theory. In studies of patients with frontal lobe epilepsy, the increase in Co and/or $\mathrm{Cr}$ levels was found more significant than the NAA decrease and this finding was thought to reflect high metabolic activity and/ or gliosis in glial cells (20). In addition, a decrease in NAA level and increase in Co and $\mathrm{Cr}$ levels in MRS studies that examined temporal lobes were similarly found (12) and this increase was linked to gliosis, as these metabolites were found mostly in oligodendrocytes and astrocytes. In our study, the increase in mean frontal lobe $\mathrm{Co}$ and $\mathrm{Co} / \mathrm{Cr}$ values in all patients with GGE, especially in those with recurrent ASE episodes compared with controls was more pronounced than NAA decrease. This led to the idea that the increase in frontal lobe Co levels and $\mathrm{Co} /$ Cr ratio may be a common finding in all patients with GGE and ASE episodes might be closely related to the decrease in NAA levels and NAA/Cr ratio. Detection of increased levels of glutamate, which causes an increase in neuronal excitability in the prefrontal cortex, also supports the notion of a frontal metabolic disorder and an increase in glutamatergic excitatory structures (14).

\section{Conclusion}

Although we had few patients due to the rarity of this disease, frontal lobe and thalamic neurochemical disorders detected in all patients with GGE suggest a thalamocortical network disorder in the etiopathogenesis of ASE. In addition, the more pronounced neurochemical disorder in patients with recurrent
ASE episodes gave the impression that ASE episodes might be of thalamocortical network origin and these episodes might increase the existing damage involved in the pathogenesis. However, these findings should be supported by further studies including more patients with recurrent ASE episodes and/or implementation of new imaging methods.

\section{Ethics}

Ethics Committee Approval: The study was approved by the Istanbul University Ethics Committee.

Informed Consent: Consent form was filled out by all participants. Peer-review: Externally peer-reviewed.

\section{Autborship Contributions}

Medical Practices: Zeynep Aydın Özemir, Betül Baykan, Ebru Nur Vanlı Yavuz, Concept Zeynep Aydın Özemir, Ebru Nur Vanlı Yavuz, Design: Zeynep Aydin Özemir, Data Collection or Processing: Zeynep Aydın Özemir, Analysis or Interpretation: Zeynep Aydın Özemir, Serra Sencer, Betül Baykan, Literature Search: Zeynep Aydın Özemir, Ebru Nur Vanlı Yavuz, Writing: Zeynep Aydin Özemir.

Conflict of Interest: No conflict of interest was declared by the authors.

Financial Disclosure: This study received financial support from the Istanbul University Scientific Research Projects Foundation (number: T-391/08032004).

\section{References}

1. Trinka E, Cock H, Hesdorffer D, Rossetti AO, Scheffer IE, Shinnar S, Shorvon $\mathrm{S}$, Lowenstein DH. A definition and classification of status epilepticusReport of the ILAE Task Force on Classification of Status Epilepticus. Epilepsia 2015;56:1515-1523.

2. Betjemann JP, Lowenstein DH. Status epilepticus in adults. The Lancet Neurology 2015;14:615-624.

3. Cascino GD. Nonconvulsive status epilepticus in adults and children. Epilepsia 1993;34:21-28.

4. Shorvon S, Trinka E. The 5th London-Innsbruck Colloquium on Status Epilepticus and Acute Seizures. Epilepsy Behav 2015;49:1-3. 
5. Naylor DE, Liu H, Niquet J, Wasterlain CG. Rapid surface accumulation of NMDA receptors increases glutamatergic excitation during status epilepticus. Neurobiol Dis 2013;54:225-238.

6. Cock HR, Tong X, Hargreaves IP, Heales SJ, Clark JB, Patsalos PN, Thom M, Groves M, Schapira AHV, Shorvon SD, Walker MC. Mitochondrial dysfunction associated with neuronal death following status epilepticus in rat. Epilepsy Res 2002;48:157-168.

7. David Y, Cacheaux LP, Ivens S, Lapilover E, Heinemann U, Kaufer D, Friedman A. Astrocytic dysfunction in epileptogenesis: Consequence of altered potassium and glutamate homeostasis? J Neurosci 2009;29:1058810599.

8. Friedman A, Dingledine R. Molecular cascades that mediate the influence of inflammation on epilepsy. Epilepsia 2011;52:33-39.

9. Marchi N, Granata T, Freri E, Ciusani E, Ragona F, Puvenna V, Teng Q, Alexopolous A, Janigro D. Efficacy of anti-inflammatory therapy in a model of acute seizures and in a population of pediatric drug resistant epileptics. PLoS One 2011;28:e18200.

10. Urenjak J, Williams SR, Gadian DG, Noble M. Proton nuclear magnetic resonans spectroscopy unambiguously identifies different neural cell types. J Neuroscience 1993;13:981-999.

11. Bjartmar C, Battistuta J, Terada N, Dupree E, Trapp BD. N-acetylaspartate is an axon-specific marker of mature white matter in vivo: A biochemical and immunohistochemical study on the rat optic nerve. Ann Neurology 2002;51:51-58.

12. Bernasconi A, Tasch E, Cendes F, Li LM, Arnold DL. Proton magnetic resonance spectroscopic imaging suggests progressive neuronal damage in human temporal lobe epilepsy. Prog Brain Res 2002;135:297-304.
13. De Stefano N, Matthews PM, Arnold DL. Reversible decreases in $\mathrm{N}$-acetylaspartate after acute brain injury. Magn Reson Med 1995;34:721727.

14. Simister RJ, McLean MA, Barker GJ, Duncan JS. Proton MRS reveals frontal lobe metabolite abnormalities in idiopathic generalized epilepsy. Neurology 2003;61:897-902

15. Savic I, Lekvall A, Greitz D, Helms G. MR spectroscopy shows reduced frontal lobe concentrations of $\mathrm{N}$-acetyl aspartate in patients with juvenile myoclonic epilepsy. Epilepsia 2000;41:290-296.

16. Bernasconi A, Bernasconi N, Natsume J, Antel SB, Andermann F, Arnold DL. Magnetic spectroscopy and imaging of the thalamus in idiopathic generalized epilepsy. Brain 2003;126:2447-2454.

17. Mory SB, Li LM, Guerreiro CAM, Cendes F. Thalamic dysfunction in juvenile myoclonic epilepsy: A proton MRS Study. Epilepsia 2003;44:1402-1405.

18. Shorvon SD. The etiologic classification of epilepsy. Epilepsia 2011;52:10521057.

19. Savic I, Osterman Y, Helms G. MRS shows syndrome differentiated metabolite changes in human-generalized epilepsies. Neuroimage 2004;21:163-172.

20. Lundbom N, Gaily E, Vuori K, Paetau R, Liukkonen E, Rajapakse JC, Valanne L, Hakkiken AM, Granström ML. Proton spectroscopic imaging shows abnormalities in glial and neuronal cell pools in frontal lobe epilepsy. Epilepsia 2001;42:1507-1514.

21. Cendes F, Caramanos Z, Andermann F, Dubeau F, Arnold DL. Proton magnetic resonance spectroscopic imaging and magnetic resonance imaging volumetry in the lateralization of temporal lobe epilepsy: A series of 100 patients. Ann Neurology 1997;42:737-746. 